\title{
Article \\ Chemical Composition and Evaluation of Insecticidal Activity of Calendula incana subsp. maritima and Laserpitium siler subsp. siculum Essential Oils against Stored Products Pests
}

\author{
Sara Basile ${ }^{1,2}$, Natale Badalamenti ${ }^{3, * \mathbb{D}}$, Ornella Riccobono ${ }^{2}$, Salvatore Guarino ${ }^{4} * \mathbb{D}$, Vincenzo Ilardi ${ }^{3}$, \\ Maurizio Bruno ${ }^{3,5}$ and Ezio Peri ${ }^{2,6}$ (D)
}

check for updates

Citation: Basile, S.; Badalamenti, N.; Riccobono, O.; Guarino, S.; Ilardi, V.; Bruno, M.; Peri, E. Chemical Composition and Evaluation of Insecticidal Activity of Calendula incana subsp. maritima and Laserpitium siler subsp. siculum Essential Oils against Stored Products Pests. Molecules 2022, 27, 588. https://doi.org/10.3390/ molecules27030588

Academic Editors: Nikos Tzortzakis and Riccardo Petrelli

Received: 9 December 2021 Accepted: 16 January 2022

Published: 18 January 2022

Publisher's Note: MDPI stays neutral with regard to jurisdictional claims in published maps and institutional affiliations.

Copyright: (C) 2022 by the authors. Licensee MDPI, Basel, Switzerland. This article is an open access article distributed under the terms and conditions of the Creative Commons Attribution (CC BY) license (https:// creativecommons.org/licenses/by/ $4.0 /)$.
1 Faculty of Forestry and Wood Sciences, Czech University of Life Sciences Prague, CULS, Kamýcká 129, 16500 Prague, Czech Republic; basile@fld.czu.cz

2 Department of Agricultural, Food and Forest Sciences (SAAF), University of Palermo, Viale delle Scienze, Building 5, 90128 Palermo, Italy; ornella.riccobono94@gmail.com (O.R.); ezio.peri@unipa.it (E.P.)

3 Department of Biological, Chemical and Pharmaceutical Sciences and Technologies (STEBICEF), Università di Palermo, Viale delle Scienze, 90128 Palermo, Italy; vincenzo.ilardi@unipa.it (V.I.); maurizio.bruno@unipa.it (M.B.)

4 Institute of Biosciences and Bioresources (IBBR), National Research Council of Italy (CNR), Corso Calatafimi 414, 90129 Palermo, Italy

5 Centro Interdipartimentale di Ricerca "Riutilizzo Bio-Based Degli Scarti da Matrici Agroalimentari" (RIVIVE), Università di Palermo, 90128 Palermo, Italy

6 Interuniversity Center for Studies on Bioinspired Agro-Environmental Technology (BAT Center), University of Napoli Federico II, 80055 Portici, Italy

* Correspondence: natale.badalamenti@unipa.it (N.B.); salvatore.guarino@ibbr.cnr.it (S.G.)

Abstract: The problems of the environment and human health related to the use of synthetic and broad-spectrum insecticides have increasingly motivated scientific research on different alternatives and among these, the use of green systems, such as essential oils, have been explored. Several species of the Apiaceae and Asteraceae families, aromatic herbs rich in secondary bioactive metabolites, are used in the industrial field for pharmaceutical, cosmetic, and food purposes. Different essential oils extracted from some species of these families have shown acute toxicity and attractive and/or repellent effects towards different insects. In our work, we investigated the toxic potential of Calendula incana subsp. maritima and Laserpitium siler subsp. siculum essential oils against four insect species, Sitophilus oryzae, Lasioderma serricorne, Necrobia rufipes, and Rhyzoperta dominica, which are common pests of stored products. The composition of both oils, extracted by hydrodistillation from the aerial parts of the two plants, was evaluated by GC $\times$ GC-MS. Calendula incana subsp. maritima essential oil was rich in oxygenated sesquiterpenoids, such as cubebol (35.39\%), 4-epi-cubebol (22.99\%), and cubenol (12.77\%), while the Laserpitium siler subsp. siculum essential oil was composed mainly of monoterpene hydrocarbons, such as $\beta$-phellandrene (42.16\%), limonene (23.87\%), and $\beta$-terpinene $(11.80 \%)$. The toxicity Petri dish bioassays indicated that C. maritima oil killed a mean of $65.50 \%$ of $S$. oryzae and $44.00 \%$ of $R$. dominica adults, indicating a higher biocidal activity in comparison with L. siculum oil, while toward the other species, no significant differences in mortality were recorded. Calendula maritima oil could be, then, considered a promising candidate for further tests as an alternative biocide toward S. oryzae and $R$. dominica. The possibility that the relatively high content of oxygenated sesquiterpenoids in C. maritima essential oil determines its higher biocidal activity is discussed.

Keywords: GC $\times$ GC-MS analysis; cubebene derivatives; Necrobia rufipes; Sitophilus oryzae; Lasioderma serricorne; Rhyzopertha dominica

\section{Introduction}

Food spoilage during storage determined by pest infestation is a major concern in both developed and developing countries, causing from 9 to $20 \%$ of product losses and 
consequent strong economic impact in terms of quality and market access [1,2]. Stored food products are reported to potentially be affected by about 1660 insect species worldwide [3], the most dangerous of them mainly belonging to only three orders, Coleoptera (beetles), Lepidoptera (moths), and Psocoptera (psocids) [4]. In the past, stored product pests have been mainly controlled by synthetic contact pesticides [5]. However, this approach determined increasing resistance phenomena [6] and had a negative impact on the environment and human health $[7,8]$.

The drawbacks of the widespread use of chemical insecticides at ecotoxicological, environmental, and social levels have led researchers to find suitable alternatives that are more environmentally friendly than synthetic chemicals in the management of stored product pests [9]. Recently, the guidelines of the European Union have been aimed at a reduction in the use of synthetic chemicals in favour of other eco-friendlier approaches based on natural products [10]. In this context, the use of insecticides based on plant extracts is attracting extensive attention both among researchers and consumers [9]. In detail, academic interest in plant natural products with insecticidal properties has continued to develop in the past 20 years, especially in countries such as China, Iran, Turkey, and India, where regulation on the use of such botanicals have more relaxed regulatory requirements in comparison with the EU and the USA [11].

Nevertheless, despite this growing interest, many valuable plants and their metabolites have not yet been explored; therefore, it is essential to conduct new studies on various wild species to evaluate their deterrent and insecticidal properties [12].

In this regard, the use of essential oils (EOs) as natural insecticides is growing enormously, thanks to their high biodegradability and wide bioactivities [13,14]. The metabolites present in the different EOs possess multiple properties due to single action or synergistic action, such as acute toxicity, feeding and oviposition deterrence, repellence, and attraction $[15,16]$. Although the mechanisms of action are not perfectly known, several studies have shown that the greatest toxicity is caused by the interaction of the oil with the nervous system of insects mediated by the inhibition of acetylcholinesterase (AChE), or by the antagonism of octopamine receptors [17].

In this study, we investigated the EOs of two punctiform species belonging to the genus Calendula and Laserpitium growing in Sicily. The genus Calendula (Asteraceae) is distributed in all of Europe and North Africa [18]. Calendula incana subsp. maritima (Guss.) Ohle [19] [Syn. Calendula maritima Guss.; Calendula suffruticosa subsp. maritima (Guss.) Meikle], hereafter named C. maritima, is a perennial and suffruticose plant, $20-40 \mathrm{~cm}$ tall, with branched and creeping stems. The leaves, rounded at the apex, fleshy, have a pungent odor and a length of $20-45 \mathrm{~mm}$. Inflorescences in flower heads of 3-5 cm in diameter, with yellow female flowers.

Laserpitium siler subsp. siculum (Spreng.) Santangelo, F. Conti \& Gubellini [20] [Syn. Laserpitium siculum Spreng.; L. garganicum (Ten.) Bertol.; Siler siculum Thell.; L. garganicum (Ten.) Bertol. subsp. siculum (Spreng.) Pignatti; Siler montanum Crantz subsp. siculum (Spreng.) Iamonico, Bartolucci et F. Conti], hereafter named L. siculum, instead, is a herbaceous plant $2-5 \mathrm{dm}$ tall, hairless, and glaucescent. The stem is erect, streaked, with basal leaves of 1-2.5(4) dm. The umbels have 10-20 rays, and the fruit has $1.5 \mathrm{~mm}$ wide wings. It blooms between June and July. Laserpitium siculum is distributed over an area that covers the central-southern Apennine regions, Sicily, and the Dinaric Alps [21], and it is distinguished from L. garganicum (Ten.) Bertol. (endemism of central-southern Italy and Sardinia) above all for the shape and length of the bracts.

Calendula maritima and L. siculum are species that are growing in marginal lands, and their cultivation could be exploited in such contexts where other cultivated species cannot be planted. Furthermore, given the excellent results shown by the EOs obtained from different species of the Umbelliferae family [22], used as natural insecticides [23,24], and considering the insecticidal and repellent properties of the Calendula genus $[25,26]$, the object of this study was to investigate, for the first time, the chemical composition of $C$. incana subsp. maritima and L. siler subsp. siculum EOs, and to evaluate their biocidal effect on four 
species of stored products pests: Sitophilus oryzae L. (Coleoptera: Curculionidae), Lasioderma serricorne F. (Coleoptera: Anobiidae), Necrobia rufipes DeGeer (Coleoptera: Cleridae), and Rhyzoperta dominica F. (Coleoptera: Bostrichidae). These species have a worldwide distribution range and are reported as among the most dangerous for stored commodities [27-31]. Sitophilus oryzae, also known as the rice weevil, and $R$. dominica, also named as the lesser grain borer, are primary insects of cereal grains in storage, including wheat, maize, and rice [32,33]. Lasioderma serricorne, the cigarette beetle, is a cosmopolitan polyphagous pest dangerous in the food and tobacco industry in many regions of the world [34]. Necrobia rufipes, commonly named the red-legged ham beetle, is a pest of stored products of animal origin, and its infestations are an increasing problem for the pet food industry [35]. The economic damage determined by these species is both quantitative due to substrate weight loss caused by insect feeding and qualitative due to product alterations such as loss of nutritional and aesthetic value, increased levels of rejects in the grain mass, and loss of industrial characteristics $[36,37]$.

\section{Results and Discussions}

\subsection{Chemical Composition of Essential Oil}

Hydrodistillation of C. maritima aerial parts gave a yellow, dense oil. Overall, twentyfour compounds were identified, representing $95.78 \%$ of the total components, listed in Table 1 according to their retention indices on a DB- 5 MS column and classified into two main classes based on their chemical structures. Oxygenated sesquiterpenes formed the main class, representing $87.77 \%$ of the oil, with cubebol $(35.39 \%)$ as the most abundant component. In the same class, 4-epi-cubebol (22.99\%), $\tau$-muurolol (13.11\%), and cubenol $(12.77 \%)$ were also present. Sesquiterpene hydrocarbons was the other most abundant class $(7.84 \%)$, with $\alpha$-cubebene $(1.12 \%)$ and $\beta$-cubebene $(1.12 \%)$ as the main component of this class. Finally, other compounds such as monoterpenes were present in trace amounts.

From a comparison of the chemical compositions of EOs of other species belonging to the Calendula genus studied so far, it emerged that cubebane sesquiterpenes, such as $\alpha$-cubebene, $\beta$-cubebene, 4-epi-cubebol, cubebol, and cubenol, the main compounds of our oil $(60.62 \%)$, were present in a moderate amount only in some accessions of $C$. arvensis collected in Corsica [38] and C. officinalis collected in Turkey [39].

Among the other metabolites present in C. maritima, it is worth mentioning that $\tau$-muurolol occurred in some accessions of C. arvensis collected in Corsica [38] and in populations of C. officinalis from Estonia [40] and South Africa [41], and cubenol derivatives were present in C. arvensis from Corsica [38] and C. officinalis from France [42]. Only two species, C. arvensis L. collected in Turkey [43] and C. micrantha studied in Egypt [44], did not show either cubebane derivatives or sesquiterpenes with the typical cadinene skeleton. All the other EOs extracted from C. arvenis L. [45-49], on the other hand, were characterized by a large presence of bicyclic sesquiterpenes, with the so-called cadalane (4-isopropyl-1,6-dimethyldecahydronaphthalene) carbon skeleton.

Hydrodistillation of L. siculum aerial parts gave light-blue oil. Overall, thirty-eight compounds were identified, representing $99.24 \%$ of total components, listed in Table 2 according to their retention indices on a DB-5 MS column and classified into five classes based on their chemical structures. The main class was constituted by monoterpene hydrocarbons, representing $90.38 \%$ of the oil, with $\beta$-phellandrene $(42.16 \%)$, limonene $(23.87 \%)$, and $\beta$-terpinene $(11.80 \%)$ as the most abundant components. Oxygenated monoterpenes were the second most abundant class $(5.47 \%)$, with 4 -terpinenyl acetate $(5.20 \%)$ as the main component of this class. On the other hand, the other chemical classes were present in traces. Despite the blue color of the oil, the presence of chamazulene was just $0.10 \%$. 
Table 1. Compounds identified in the essential oil of Calendula incana subsp. maritima using GC $\times$ GC-MS.

\begin{tabular}{|c|c|c|c|c|c|c|c|}
\hline No & $\begin{array}{c}t^{1} R \\
\text { (min.s) }\end{array}$ & $\begin{array}{c}t^{2} R \\
\text { (min.s) }\end{array}$ & Compounds & $\mathrm{LRI}_{\exp }{ }^{\mathrm{a}}$ & $\operatorname{LRI}_{\text {lit }} \mathbf{b}$ & Content $(\%)^{c}$ & Ident. ${ }^{d}$ \\
\hline 1 & 17.08 & 1.79 & $\beta$-Pinene & 977 & 981 & $t$ & $1,2,3$ \\
\hline 2 & 17.24 & 1.63 & 2-Pentylfuran & 991 & 993 & $t$ & 1,2 \\
\hline 3 & 18.33 & 0.61 & $p$-Cymene & 1026 & 1028 & $t$ & $1,2,3$ \\
\hline 4 & 18.60 & 1.72 & Limonene & 1031 & 1028 & $t$ & $1,2,3$ \\
\hline 5 & 18.87 & 1.32 & Benzeneacetaldehyde & 1046 & 1045 & $0.08 \pm 0.001$ & $1,2,3$ \\
\hline 6 & 19.00 & 1.41 & $\beta$-Terpinene & 1048 & 1056 & $t$ & $1,2,3$ \\
\hline 7 & 20.32 & 1.83 & Nonanal & 1106 & 1109 & $t$ & 1,2 \\
\hline 8 & 25.11 & 1.86 & Decanal & 1206 & 1210 & $t$ & $1,2,3$ \\
\hline 9 & 27.13 & 1.59 & $\alpha$-Cubebene & 1359 & 1365 & $1.33 \pm 0.02$ & 1,2 \\
\hline 10 & 27.64 & 1.56 & $\alpha$-Copaene & 1387 & 1381 & $0.12 \pm 0.004$ & 1,2 \\
\hline 11 & 27.88 & 1.63 & $\beta$-Cubebene & 1391 & 1397 & $1.15 \pm 0.03$ & 1,2 \\
\hline 12 & 28.85 & 1.53 & cis-Muurola-3,5-diene & 1432 & 1431 & $1.20 \pm 0.02$ & 1,2 \\
\hline 13 & 31.83 & 1.37 & $\gamma$-Muurolene & 1479 & 1480 & $0.39 \pm 0.008$ & 1,2 \\
\hline 14 & 32.04 & 1.03 & 4-epi-Cubebol & 1491 & 1497 & $23.11 \pm 0.74$ & 1,2 \\
\hline 15 & 34.24 & 1.28 & Cubebol & 1518 & 1525 & $35.84 \pm 0.69$ & 1,2 \\
\hline 16 & 34.26 & 1.71 & $\delta$-Cadinene & 1522 & 1523 & $0.71 \pm 0.02$ & 1,2 \\
\hline 17 & 34.32 & 1.34 & $\alpha$-Calacorene & 1525 & 1526 & $0.80 \pm 0.007$ & 1,2 \\
\hline 18 & 35.21 & 0.89 & Calamenene & 1528 & 1531 & $1.02 \pm 0.02$ & 1,2 \\
\hline 19 & 35.91 & 1.13 & Cadala-1(10),3,8-triene & 1544 & 1552 & $1.43 \pm 0.07$ & 1,2 \\
\hline 20 & 36.23 & 0.81 & Ledol & 1549 & 1553 & $0.70 \pm 0.010$ & $1,2,3$ \\
\hline 21 & 40.75 & 1.27 & Cubenol & 1647 & 1648 & $12.59 \pm 0.39$ & 1,2 \\
\hline 22 & 40.84 & 1.03 & $\tau$-Muurolol & 1651 & 1654 & $13.15 \pm 0.44$ & 1,2 \\
\hline 23 & 40.91 & 1.42 & Ledene oxide-(II) & 1653 & 1655 & $2.19 \pm 0.08$ & 1,2 \\
\hline 24 & 57.83 & 0.84 & $\begin{array}{l}\text { Hexahydrofarnesyl } \\
\text { acetone }\end{array}$ & 1842 & 1845 & $0.59 \pm 0.010$ & 1,2 \\
\hline \multirow{4}{*}{\multicolumn{6}{|c|}{$\begin{array}{c}\text { Monoterpene Hydrocarbons } \\
\text { Sesquiterpene Hydrocarbons } \\
\text { Oxygenated Sesquiterpenes } \\
\text { Others }\end{array}$}} & \multicolumn{2}{|c|}{$t$} \\
\hline & & & & & & \multicolumn{2}{|c|}{$8.150 \pm 0.199$} \\
\hline & & & & & & \multicolumn{2}{|c|}{$8817+2360$} \\
\hline & & & & & & \multicolumn{2}{|c|}{$0.090 \pm 0.002$} \\
\hline \multicolumn{6}{|c|}{ Total } & \multicolumn{2}{|c|}{$96.410 \pm 2.561$} \\
\hline
\end{tabular}

$\mathrm{t}^{1} \mathrm{R}$ : first dimension retention time (minutes.seconds); $\mathrm{t}^{2} \mathrm{R}$ : second dimension retention time. ${ }^{a}$ Linear retention index, obtained through the modulated chromatogram, reported for DB-5 MS apolar column; ${ }^{\mathrm{b}}$ Linear retention index reported for DB-5 MS column or equivalents reported in the literature; ${ }^{\mathrm{C}}$ Content is the peak volume percentage of compounds in the essential oil sample; ${ }^{\mathrm{d}}: 1=$ retention index identical to bibliography; $2=$ identification based on comparison of MS; 3 = retention time identical to authentic compounds; $t$ : traces, $<0.05 \%$. Compounds are classified in order of linear retention time of the apolar column.

The presence of $\beta$-phellandrene, the main component of L. siculum, has been reported, only in moderate amount, in L. garganicum (14.4\%) from Italy [50], L. latifolium from Stara Planina, Serbia (3.2\%) [51] and Mt. Gučevo, Serbia (11.8\%) [52], L. pseudomeum from Greece (6.7\%) [53], and L. zernyi from Macedonia and Serbia (12.0-4.3\%) [54]. Although several other EOs of previously studied taxa of Laserpitium showed to be particularly rich in monoterpene hydrocarbons, this compound was absent in L. carduchorum [55], L. latifolium [51,52,56], L. petrophilum [57], and L. pseudomeum [53]. It is interesting to point out that the only other accession of L. siculum studied so far, from plants collected in Central Italy [58], showed a completely different composition of the EO in comparison with our results, with a presence of monoterpene hydrocarbons ranging from 40.0 to $31.5 \%$ and abundant sesquiterpenes ranging from 39.3 to $20.4 \%$. In this case, chamazulene occurred in quite a high amount (32.2-17.0\%). 
Table 2. Compounds identified in the essential oil of Laserpitium siler subsp. siculum using GC $\times$ GC-MS.

\begin{tabular}{|c|c|c|c|c|c|c|c|}
\hline No & $\begin{array}{c}\mathbf{t}^{1} \mathbf{R} \\
\text { (min.s) }\end{array}$ & $\begin{array}{c}\mathrm{t}^{2}{ }_{\mathrm{R}} \\
\text { (min.s) }\end{array}$ & Compounds & LRI $_{\exp }{ }^{a}$ & LRI $_{l i t} b$ & Content $(\%)^{c}$ & Ident. ${ }^{d}$ \\
\hline 1 & 12.59 & 0.68 & 3-Hexanone & 782 & 775 & $t$ & 1,2 \\
\hline 2 & 13.05 & 0.94 & 2-Hexanone & 798 & 791 & $t$ & $1,2,3$ \\
\hline 3 & 14.91 & 1.30 & cis-4-Nonene & 891 & 885 & $0.07 \pm 0.002$ & 1,2 \\
\hline 4 & 16.19 & 1.46 & $\alpha$-Pinene & 937 & 936 & $t$ & $1,2,3$ \\
\hline 5 & 16.72 & 1.56 & Camphene & 959 & 954 & $0.93 \pm 0.010$ & $1,2,3$ \\
\hline 6 & 17.02 & 1.77 & $\beta$-Pinene & 977 & 981 & $3.14 \pm 0.15$ & $1,2,3$ \\
\hline 7 & 17.29 & 1.67 & 2-Butyltetrahydro-furan & 999 & 986 & $t$ & 1,2 \\
\hline 8 & 17.50 & 1.72 & 2-Carene & 1001 & 1003 & $2.07 \pm 0.04$ & 1,2 \\
\hline 9 & 17.62 & 1.51 & $\alpha$-Phellandrene & 1003 & 1005 & $0.38 \pm 0.010$ & $1,2,3$ \\
\hline 10 & 17.91 & 1.15 & Sylvestrene & 1014 & 1021 & $0.11 \pm 0.004$ & 1,2 \\
\hline 11 & 17.96 & 1.62 & 3-Carene & 1015 & 1010 & $0.23 \pm 0.001$ & 1,2 \\
\hline 12 & 18.23 & 1.82 & $\alpha$-Terpinene & 1019 & 1017 & $3.57 \pm 0.11$ & $1,2,3$ \\
\hline 13 & 18.37 & 1.93 & 4-Carene & 1022 & 1018 & $0.82 \pm 0.010$ & 1,2 \\
\hline 14 & 18.40 & 0.63 & $o$-Cymene & 1023 & 1022 & $0.55 \pm 0.02$ & 1,2 \\
\hline 15 & 18.56 & 1.72 & $\beta$-Phellandrene & 1029 & 1028 & $41.98 \pm 0.93$ & $1,2,3$ \\
\hline 16 & 18.60 & 1.72 & Limonene & 1031 & 1028 & $23.76 \pm 0.78$ & $1,2,3$ \\
\hline 17 & 19.00 & 1.41 & $\beta$-Terpinene & 1048 & 1056 & $11.83 \pm 0.08$ & $1,2,3$ \\
\hline 18 & 19.73 & 2.03 & $\alpha$-Terpinolene & 1082 & 1087 & $0.73 \pm 0.02$ & 1,2 \\
\hline 19 & 19.99 & 1.62 & 2,4-Dimethylstyrene & 1089 & - & $0.09 \pm 0.003$ & 1,2 \\
\hline 20 & 25.15 & 1.77 & $\alpha$-Terpineol & 1207 & 1199 & $0.19 \pm 0.002$ & $1,2,3$ \\
\hline 21 & 26.54 & 2.14 & 4-Terpinenyl acetate & 1291 & 1282 & $5.28 \pm 0.24$ & 1,2 \\
\hline 22 & 27.28 & 1.62 & $\beta$-Bourbonene & 1368 & 1385 & $t$ & 1,2 \\
\hline 23 & 27.31 & 1.82 & $\alpha$-Ylangene & 1369 & 1373 & $t$ & 1,2 \\
\hline 24 & 27.64 & 1.56 & $\alpha$-Copaene & 1387 & 1381 & $0.15 \pm 0.003$ & 1,2 \\
\hline 25 & 27.93 & 1.98 & 1,7-Dimethylnaphthalene & 1396 & 1410 & $0.05 \pm 0.001$ & 1,2 \\
\hline 26 & 28.53 & 1.77 & Caryophyllene & 1425 & 1417 & $1.12 \pm 0.03$ & $1,2,3$ \\
\hline 27 & 28.61 & 1.98 & $\beta$-Ylangene & 1427 & 1422 & $0.59 \pm 0.010$ & 1,2 \\
\hline 28 & 28.87 & 1.51 & $\beta$-Copaene & 1433 & 1432 & $t$ & 1,2 \\
\hline 29 & 29.45 & 1.62 & $\gamma$-Elemene & 1439 & 1434 & $0.21 \pm 0.004$ & 1,2 \\
\hline 30 & 30.01 & 1.98 & Humulene & 1455 & 1453 & $0.12 \pm 0.002$ & 1,2 \\
\hline 31 & 31.17 & 2.03 & Patchoulene & 1468 & 1467 & $0.44 \pm 0.007$ & 1,2 \\
\hline 32 & 31.79 & 0.63 & $\alpha$-Curcumene & 1478 & 1483 & $0.06 \pm 0.001$ & 1,2 \\
\hline 33 & 33.66 & 0.21 & $\alpha$-Bulnesene & 1511 & 1506 & $0.09 \pm 0.006$ & 1,2 \\
\hline 34 & 34.21 & 0.31 & $\delta$-Cadinene & 1519 & 1522 & $0.16 \pm 0.009$ & 1,2 \\
\hline 35 & 35.43 & 0.99 & $\beta$-Vatirenene & 1536 & 1542 & $0.09 \pm 0.006$ & 1,2 \\
\hline 36 & 42.67 & 1.88 & trans-Nuciferol & 1698 & - & $0.19 \pm 0.008$ & 1,2 \\
\hline 37 & 48.07 & 1.93 & $\beta$-Nootkatol & 1725 & 1712 & $0.05 \pm 0.002$ & 1,2 \\
\hline 38 & 51.15 & 0.63 & Chamazulene & 1731 & 1730 & $0.13 \pm 0.005$ & 1,2 \\
\hline \multicolumn{6}{|c|}{ Monoterpene Hydrocarbons } & \multicolumn{2}{|c|}{$90.19 \pm 2.168$} \\
\hline \multicolumn{6}{|c|}{ Oxygenated Monoterpenes } & \multicolumn{2}{|c|}{$5.47 \pm 0.242$} \\
\hline \multicolumn{6}{|c|}{ Sesquiterpene Hydrocarbons } & \multicolumn{2}{|c|}{$3.16 \pm 0.083$} \\
\hline \multicolumn{6}{|c|}{ Oxygenated Sesquiterpenes } & \multicolumn{2}{|c|}{$0.24 \pm 0.010$} \\
\hline \multicolumn{6}{|c|}{ Others } & \multicolumn{2}{|c|}{$0.13 \pm 0.004$} \\
\hline \multicolumn{6}{|c|}{ Total } & \multicolumn{2}{|c|}{$99.19 \pm 2.507$} \\
\hline
\end{tabular}

$\mathrm{t}_{\mathrm{R}}^{1}$ : first dimension retention time (minutes.seconds); $\mathrm{t}^{2} \mathrm{R}$ : second dimension retention time. ${ }^{\mathrm{a}}$ Linear retention index, obtained through the modulated chromatogram, reported for DB-5 MS apolar column; ${ }^{\mathrm{b}}$ Linear retention index reported for DB-5 MS column or equivalents reported in the literature; ${ }^{\mathrm{C}}$ Content is the peak volume percentage of compounds in the essential oil sample; ${ }^{\mathrm{d}}: 1=$ retention index identical to bibliography; $2=$ identification based on comparison of MS; 3 = retention time identical to authentic compounds; $t$ : traces, $<0.05 \%$. Compounds are classified in order of linear retention time of the apolar column.

\subsection{Toxicity Bioassays}

The biocidal effect of C. maritima and L. siculum EOs on S. oryzae, R. dominica, N. rufipes, and L. serricorne is reported in Figure 1. On S. oryzae, the EOs tested determined a different level of mortality $\left(\mathrm{F}_{2,27}=6.63 ; p<0.01\right.$; ANOVA $)$, with the $C$. maritima $\mathrm{EO}$ that determined a $64.50 \%$ of dead adults, a value higher than using solvent $(p<0.001)$ or L. siculum EO 
$(p<0.05)$, while no statistical differences were recorded in the adult mortality between $L$. siculum and the solvent $(p=\mathrm{ns})$. Similarly, the use of EOs toward R. dominica, determined differences statistically different in adult mortality $\left(\mathrm{F}_{2.27}=8.56 ; p=0.001\right.$; ANOVA), with $C$. maritima EO that determined a $44.00 \%$ of dead adults, a value higher than using solvent $(p<0.001)$ or L. siculum EO $(p<0.05)$, while no statistical differences were recorded in the adult mortality between L. siculum and the solvent ( $p=\mathrm{ns})$. Differently, the EOs tested didn't determine differences in mortality levels toward N. rufipes $\left(\mathrm{F}_{2.27}=0.72 ; p=\mathrm{ns}\right.$; ANOVA) and L. serricorne $\left(\mathrm{F}_{2.27}=2.12 ; p=\mathrm{ns}\right.$; ANOVA), in comparison with the solvent.
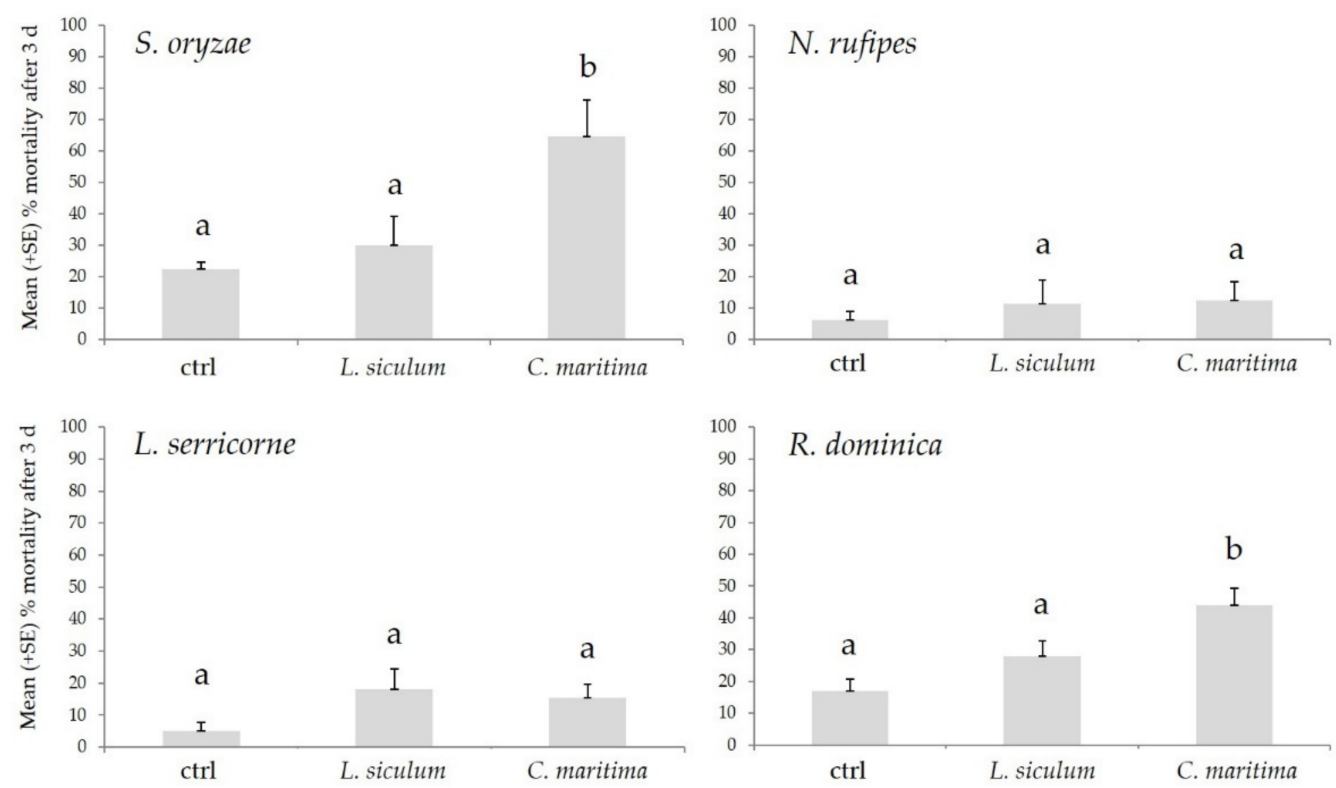

Figure 1. Mean (+SE) \% adult mortality after three days (d) from treatment determined by Calendula incana subsp. maritima and Laserpitium siler subsp. siculum toward Sitophilus oryzae, Necrobia rufipes, Lasioderma serricorne, and Rhyzoperta dominica. Different letters indicate statistically significant differences $(p<0.05)$ among the treatments (one-way ANOVA, followed by Tukey's test).

Overall, these results indicate a clear toxicity effect of $C$. maritima EO exerted on $S$. oryzae and $R$. dominica. The deterrent effect toward insects of extracts obtained from plants belonging to the Calendula genus has already been reported in a few studies, but this is the first time it is observed from C. maritima. For example, Tavassoli and coworkers [25] observed that $C$. officinalis EOs has a repellent effect on the mosquito Anopheles stephensi Liston, similar to DEET, the most common repellent used worldwide. In another study, a C. officinalis extract was effective in reducing infestation of brassica pest insects such as the aphid Brevicoryne brassicae L., the beetles Phyllotreta atra F. and P. nemorum L., and the lepidopterans Pieris rapae L. and Mamestra brassicae L. [59]. Furthermore, a C. arvensis extract also determined toxic effects toward a few stored pest beetles, such as Callosobruchus analis Pic and Tribolium castaneum (Herbst) [26].

It is likely that the effect of $C$. maritima $\mathrm{EO}$ on the physiology of the tested insect is mainly related to the alteration of processes in the nervous system, such as the inhibition of acetylcholinesterase and positive allosteric modulation of GABA receptors that modify the neuronal activity, which, in turn, produce malfunctioning of nerve cells, as observed in other insects and mites [60-62]. However, in other cases, it has also been documented that EOs are modulators of the octopamine and tyramine receptors [63]. Furthermore, some EOs or their components can produce lipid peroxidation, increase the ionic permeability of the cell membrane, affect the integrity of DNA, and alter mitochondrial respiration $[64,65]$.

The results obtained in our study, which indicate a strong biological activity toward S. oryzae and R. dominica, are probably determined by the high percentage of sesquiterpenes present in the $C$. maritima $\mathrm{EO}$. Few studies suggest that sesquiterpenes present in 
plant leaves provide their primary chemical defenses against pathogens and insects by discouraging the herbivores activity by deterring substances [66].

In this context, the relevant amount of cubebol present in C. maritima EO could play an important role in deterring pests due to its potential toxic activity already reported in the literature of other EOs rich in this chemical $[67,68]$. Furthermore, the bioactivity of cubebol toward other insect species was suggested by testing the EOs of the leaves of Psidium littorale Raddi (Myrtaceae), rich in this sesquiterpene, against the larvae of Anopheles gambiae Giles (Diptera: Culicidae), evidencing high toxicity [68]. Additionally, $\mathrm{Gu}$ and coworkers [67] highlighted the role played by this molecule in its pure state when evaluating the insecticidal activity of the ethanolic extract of Cryptomeria japonica (D. Don) on larvae of the mosquitoes Aedes albopictus Skuse and Aedes aegypti L. Among the other main compounds present in C. maritima EO, cubenol can also have primary importance in determining the results obtained. In fact, this oxygenated sesquiterpene is highly present in the EO of Pilgerodendron uviferum (D. Don) Florin (Cupressaceae) that evidenced antifeedant effect toward Hylastinus obscurus Marsham (Coleoptera: Curculionidae) [69]. Similarly, muurolol, representing $13.11 \%$ of the total amount of $C$. maritima EO, was also one of the main components of Zanthoxylum dissitum Hemsl leaves and root extract, exhibiting toxicity toward the beetles L. serricorne, T. castaneum, and Attagenus piceus Olivier [70]. Among the other molecules present in this EO, $\beta$-cubenene has been found in echinacea oil, which has demonstrated strong insecticidal activity toward S. granarius and T. castaneum [71].

So far, no studies have been reported in the literature about the test of such molecules used singly or combined, and this can be the object of future experiments toward these species.

Concerning the L. siculum EO, our study did not evidence insecticidal activity toward the species tested even if the main monoterpenes present in the oils, such as limonene or phellandrene, have been reported to be toxic for stored product species. In fact, other EOs such as those extracted from Pistacia lentiscus L. and Mentha haplocalyx L., rich in these two monoterpenes, evidenced contact or fumigant toxicity toward L. serricorne [70,72].

In conclusion of our work, the experimental data obtained showed that the EOs tested exhibited promising bioactivity, in particular against S. oryzae. As we tested the whole EO and not its components singly, it is not possible to establish if the bioactivity was determined by a particular chemical or by the synergistic effect of the blend. However, in consideration of the data obtained in this study, the C. maritima EO and its main chemical constituents can be considered a promising candidate for further experiments in the laboratory and semi-field studies, in order to evaluate the $\mathrm{LD}_{50}$, the repellent properties, and the ability of such oils to protect the commodities from infestation by the stored pest.

\section{Materials and Methods}

\subsection{Plant Materials and Essential Oils Extraction}

The whole aerial parts of $C$. maritima were collected from the Trapani (Sicily) seafront near the Tonnara Tipa $\left(38^{\circ} 01^{\prime} 58.29^{\prime \prime} \mathrm{N} ; 12^{\circ} 31^{\prime} 39.60^{\prime \prime} \mathrm{E}\right)$, in May 2021. A voucher of the population analyzed was deposited in the herbarium of the University of Palermo (Voucher no. 109721). On the other hand, L. siler subsp. siculum aerial parts were sampled on Madonie Mountains (Sicily), on dolomitic slopes near Contrada Quacella $\left(37^{\circ} 50^{\prime} 44.94^{\prime \prime} \mathrm{N}\right.$; $14^{\circ} 01^{\prime} 12.73^{\prime \prime}$ E) $1500 \mathrm{~m}$ above sea level, in May 2020. A voucher of the population analysed was deposited in the herbarium of the University of Palermo (Voucher no. 109716).

A variable quantity of the dried aerial parts of L. siculum and C. maritima (155.00 and $1128.00 \mathrm{~g}$, respectively) were ground and subjected to hydrodistillation for a period of $3 \mathrm{~h}$ using Clevenger's apparatus (European Pharmacopoeia, 2020). The oils (yields $0.63 \%(v / w)$ and $0.09 \%(v / w)$, respectively) were dried with anhydrous sodium sulphate, filtered, and stored in the freezer at $-20^{\circ} \mathrm{C}$, until the time of analysis. 


\subsection{GC $\times$ GC-MS Analyses}

One $\mu \mathrm{L}$ of diluted EOs $(2 / 100 v / v$, in $n$-hexane) was injected into an Agilent $7000 \mathrm{C}$ GC (Agilent, Santa Clara, CA, USA) system equipped with a split/splitless injector and a GERSTEL automatic sampler (GERSTEL, Linthicum, MD, USA). The first column set was composed of a fused silica Agilent DB-5 MS capillary column $(30 \mathrm{~m} \times 0.25 \mathrm{~mm}$ I.D.; $0.25 \mu \mathrm{m}$ film thickness, Agilent, Santa Clara, USA) connected by a modulator (G3486ACFT, Agilent, Santa Clara, CA, USA), to one segment of HP-INNOWAX $(5 \mathrm{~m} \times 0.250 \mathrm{~mm}$ i.d. $\times 0.15 \mu \mathrm{m}$ film thickness, Agilent, Santa Clara, CA, USA). For the 2D column connected to the MS detector, a $0.50 \mathrm{~m}$ segment was used. A constant inlet pressure of $21.32 \mathrm{psi}$ was selected to obtain a fixed split ratio between the two columns of about 1:20. The oven was programmed as $40{ }^{\circ} \mathrm{C}$ for $5 \mathrm{~min}$, then gradually increased to $250{ }^{\circ} \mathrm{C}$ at $2{ }^{\circ} \mathrm{C} / \mathrm{min}$ rate. Held for $15 \mathrm{~min}$ and finally raised to $270{ }^{\circ} \mathrm{C}$ at $10{ }^{\circ} \mathrm{C} / \mathrm{min}$. One $\mu \mathrm{L}$ of samples was injected at $250{ }^{\circ} \mathrm{C}$ automatically and in the splitless mode; Transfer line temperature, $270{ }^{\circ} \mathrm{C}$.; Inlet pressure of carrier gas (He) was 21.32 psi (kept constant); Modulation delay 0.01 min; Modulation period $1.6 \mathrm{~s}$; Inject time $0.15 \mathrm{~s}$. MS conditions were as follows: Ionization voltage $70 \mathrm{eV}$; Transfer line temperature $280^{\circ} \mathrm{C}$; Interval scan: $35-300 \mathrm{~m} / z$; Scan speed: $10,000 \mathrm{amu} \cdot \mathrm{s}^{-1}$ $(25 \mathrm{~Hz})$. Helium was the carrier gas $(1 \mathrm{~mL} / \mathrm{min})$. GC Image R2.4 GC $\times \mathrm{GC}$ software was utilized for data acquisition and analysis. Identification of several compounds was carried out by comparing each compound mass spectra with in-house NIST 11, Wiley 9, and FFNSC 2 mass spectral database. The criterion for accepting a detected compound was a minimum of $90 \%$ similarity with the library. These identifications were also confirmed by other published mass spectra and linear retention indices (LRI). Linear retention indices were calculated using a series of $n$-alkanes $\left(\mathrm{C}_{8}-\mathrm{C}_{40}\right)$. In addition, some of the compounds were confirmed by comparison of mass spectra and retention times with standard compounds.

\subsection{Insects}

Insect cultures were maintained at the Department of Agriculture Food and Forest Science at the University of Palermo (Italy) in the climatic room at $25 \pm 2{ }^{\circ} \mathrm{C}, 50-60 \%$ r.h., and a 16:8 light:dark photoperiod. Different species were kept separated in plastic cages $(25 \times 25 \times 40 \mathrm{~cm})$ with two 5 -cm diameter mesh-covered holes for ventilation. Sitophilus oryzae were fed with a mixture of wheat flour and rice 1:1 $w / w ;$; serricorne were fed with a mixture containing chamomile powder (100 g), 00 flour $(95 \mathrm{~g}), 0$ flour $(60 \mathrm{~g})$, bran (40 g), and brewer's yeast ( $5 \mathrm{~g}) ; R$. dominica colony was fed with whole wheat grains; $N$. rufipes colony was fed with a mixture of pet food enriched with dried fish and ham.

\subsection{Toxicity Bioassays}

Bioassays to evaluate the contact/fumigation toxicity of C. maritima and L. siculum EOs against S. oryzae, L. serricorne, N. rufipes, and R. dominica were carried out using $9-\mathrm{cm}$ diameter glass Petri dishes. EOs were diluted in $n$-hexane ( $>99 \%$, Sigma-Aldrich, Milan, Italy) at the concentration of $1 \%$. An aliquot of $100 \mu \mathrm{L}$ was gently pipetted in each internal face of the Petri dishes to cover all the surface. After 2 min for solvent evaporation, adult insects were released inside the Petri dishes with $2 \mathrm{~g}$ of food (same used for rearing). In consideration of the different adult sizes of the species tested and the availability of individuals of a similar age, for each replication, we used the following numbers of adults: twenty S. oryzae, twenty L. serricorne, eight $N$. rufipes, and ten $R$. dominica. Ten replications of each bioassay were carried out for each species and EO. As a control, an equal number of replications was carried out by pipetting $100 \mu \mathrm{L}$ of $n$-hexane. After the start of the experiments, Petri dishes containing the individuals were transferred to the climatic room at $25 \pm 2{ }^{\circ} \mathrm{C}$ and 16:8 L:D conditions. Toxicity was evaluated in terms of mortality by counting dead insects three days after the start of the experiment. Data obtained were analyzed using a one/way ANOVA, followed by Tukey's test using STATISTICA 10.0 for Windows (Statsoft, Vigonza, PD, Italy). 


\begin{abstract}
Author Contributions: Conceptualization, S.G., E.P., N.B. and M.B.; methodology, S.G., E.P., V.I., N.B. and M.B.; formal analysis, N.B., M.B., S.G. and S.B.; investigation, S.B., O.R., N.B. and V.I.; resources, M.B., V.I.; data curation, S.B., S.G., N.B.; writing-original draft preparation, N.B. and S.G.; writing-review and editing, E.P., M.B. and S.B.; visualization, V.I. and O.R.; supervision, M.B. and E.P.; funding acquisition, M.B. Plant species were collected and identified by V.I. All authors have read and agreed to the published version of the manuscript.
\end{abstract}

Funding: This work was supported by a grant from MIUR-ITALY PRIN 2017 (Project N. 2017A95NCJ).

Institutional Review Board Statement: The study was conducted according to the guidelines of the Declaration of Helsinki.

Informed Consent Statement: Not applicable.

Data Availability Statement: The data presented in this study are available on request from the corresponding authors.

Conflicts of Interest: The authors declare no conflict of interest.

Sample Availability: Samples of the compounds of C. maritima and L. siculum are available from the authors.

\title{
References
}

1. Hasan, M.M.; Phillips, T.W. Mass-rearing of the redlegged ham beetle, Necrobia rufipes De Geer (Coleoptera: Cleridae) for laboratory research. J. Stored Prod. Res. 2010, 46, 38-42. [CrossRef]

2. Kumar, D.; Kalita, P. Reducing postharvest losses during storage of grain crops to strengthen food security in developing countries. Foods 2017, 6, 8. [CrossRef]

3. Semeao, A.A.; Campbell, J.F.; Hutchinson, J.S.; Whitworth, R.J.; Sloderbeck, P.E. Spatio-temporal distribution of stored-product insects around food processing and storage facilities. Agric. Ecosyst. Environ. 2013, 165, 151-162. [CrossRef]

4. Nayak, M.K.; Daglish, G.J. Importance of stored product insects. In Recent Advances in Stored Product Protection; Springer: Berlin, Heidelberg, 2018; pp. 1-17. [CrossRef]

5. Stejskal, V.; Vendl, T.; Aulicky, R.; Athanassiou, C. Synthetic and natural insecticides: Gas, liquid, gel and solid formulations for stored-product and food-industry pest control. Insects 2021, 12, 590. [CrossRef]

6. Attia, M.A.; Wahba, T.F.; Shaarawy, N.; Moustafa, F.I.; Guedes, R.N.C.; Dewer, Y. Stored grain pest prevalence and insecticide resistance in Egyptian populations of the red flour beetle Tribolium castaneum (Herbst) and the rice weevil Sitophilus oryzae (L.). J. Stored Prod. Res. 2020, 87, 101611. [CrossRef]

7. Han, W.; Tian, Y.; Shen, X. Human exposure to neonicotinoid insecticides and the evaluation of their potential toxicity: An overview. Chemosphere 2018, 192, 59-65. [CrossRef]

8. Badr, A.M. Organophosphate toxicity: Updates of malathion potential toxic effects in mammals and potential treatments. Environ. Sci. Pollut. Res. 2020, 27, 21. [CrossRef] [PubMed]

9. Campolo, O.; Giunti, G.; Russo, A.; Palmeri, V.; Zappalà, L. Essential oils in stored product insect pest control. J. Food Qual. 2018, 6906105, 1-18. [CrossRef]

10. Kavallieratos, N.G.; Boukouvala, M.C.; Ntalli, N.; Skourti, A.; Karagianni, E.S.; Nika, E.P.; Kontodimas, D.C.; Cappellacci, L.; Petrelli, R.; Cianfaglione, K.; et al. Effectiveness of eight essential oils against two key stored-product beetles, Prostephanus truncatus (Horn) and Trogoderma granarium Everts. Food Chem. Toxicol. 2020, 139, 111255. [CrossRef]

11. Isman, M.B. Botanical insecticides in the twenty-first century-fulfilling their promise? Annu. Rev. Entomol. 2020, 65, 233-249. [CrossRef] [PubMed]

12. Tlak Gajger, I.; Dar, S.A. Plant allelochemicals as sources of insecticides. Insects 2021, 12, 189. [CrossRef]

13. Régnault-Roger, C.; Vincent, C.; Arnason, J.T. Essential oil in insect control: Low-risk products in a high-stakes world. Annu. Rev. Entomol. 2021, 57, 405-424. [CrossRef] [PubMed]

14. Miresmailli, S.; Isman, M.B. Botanical insecticides inspired by plant-herbivore chemical interactions. Trends Plant Sci. 2014, 19, 29-35. [CrossRef] [PubMed]

15. Hummelbrunner, L.A.; Isman, M.B. Acute, sublethal, antifeedant, and synergistic effects of monoterpenoid essential oil compounds on the tobacco cutworm, Spodoptera litura (Lep.; Noctuidae). J. Agric. Food Chem. 2001, 49, 715-720. [CrossRef] [PubMed]

16. Zhang, Q.H.; Schneidmiller, R.G.; Hoover, D.R. Essential oils and their compositions as spatial repellents for pestiferous social wasps. Pest Manag. Sci. 2013, 69, 542-552. [CrossRef]

17. Kostyukovsky, M.; Rafaeli, A.; Gileadi, C.; Demchenko, N.; Shaaya, E. Activation of octopaminergic receptors by essential oil constituents isolated from aromatic plants: Possible mode of action against insect pests. Pest Manag. Sci. 2002, 58, 1101-1106. [CrossRef]

18. Arora, D.; Rani, A.; Sharma, A. A review on phytochemistry and ethnopharmacological aspects of genus Calendula. Pharmacogn Rev. 2013, 7, 179-187. [CrossRef] 
19. Ohle, H. Beiträge zur Taxonomie der Gattung Calendula II. Taxonomische revision der südeuropäischen perennierende CalendulaSippen. Feddes Rep. 1974, 85, 245-283. [CrossRef]

20. Conti, F.; Abbate, G.; Alessandrini, A.; Blasi, C. An Annotated Checklist of the Italian Vascular Flora; Palombi: Rome, Italy, 2005; p. 278.

21. Pignatti, S. Flora d'Italia, 2nd ed.; Edagricole: Bologna, Italy, 2018; Volume 3, pp. 618-621.

22. Spinozzi, E.; Maggi, F.; Bonacucina, G.; Pavela, R.; Boukouvala, M.C.; Kavallieratos, N.G.; Canale, A.; Romano, D.; Desneux, N.; Wilke, A.B.B.; et al. Apiaceae essential oils and their constituents as insecticides against mosquitoes-A review. Ind. Crops Prod. 2021, 171, 113892. [CrossRef]

23. Badalamenti, N.; Ilardi, V.; Bruno, M.; Pavela, R.; Boukouvala, M.C.; Kavallieratos, N.G.; Maggi, F.; Canale, A.; Benelli, G. Chemical composition and broad-spectrum insecticidal activity of the flower essential oil from an ancient sicilian food plant, Ridolfia segetum. Agriculture 2021, 11, 304. [CrossRef]

24. Pavela, R.; Maggi, F.; Cianfaglione, K.; Canale, A.; Benelli, G. Promising insecticidal efficacy of the essential oils from the halophyte Echinophora spinosa (Apiaceae) growing in Corsica Island, France. Environ. Sci. Pollut. Res. 2020, 27, 14454-14464. [CrossRef]

25. Tavassoli, M.; Shayeghi, M.; Abai, M.R.; Vatandoost, H.; Khoobdel, M.; Salari, M.; Ghaderi, A.; Rafi, F. Repellency effects of essential oils of myrtle (Myrtus communis), Marigold (Calendula officinalis) compared with DEET against Anopheles stephensi on human volunteers. Iran. J. Arthropod-Borne Dis. 2011, 5, 10.

26. Ullah, R.; Ibrar, M.; Shah, S.; Hameed, I. Phytotoxic, cytotoxic and insecticidal activities of Calendula arvensis L. J. Biotechnol. Pharm. Res. 2012, 3, 104-111.

27. Trematerra, P.; Fontana, F.; Mancini, M.; Sciarretta, A. Influence of intact and damaged cereal kernels on the behaviour of rice weevil, Sitophilus oryzae (L.) (Coleoptera: Curculionidae). J. Stored Prod. Res. 1999, 35, 265-276. [CrossRef]

28. Arthur, F.H.; Ondier, G.O.; Siebenmorgen, T.J. Impact of Rhyzopertha dominica (F.) on quality parameters of milled rice. J. Stored Prod. Res. 2012, 48, 137-142. [CrossRef]

29. Hasan, M.M.; Athanassiou, C.G.; Schilling, M.W.; Phillips, T.W. Biology and management of the red-legged ham beetle, Necrobia rufipes DeGeer (Coleoptera: Cleridae). J. Stored Prod. Res. 2020, 88, 101635. [CrossRef]

30. Guarino, S.; Basile, S.; Caimi, M.; Carratello, A.; Manachini, B.; Peri, E. Insect pests of the Herbarium of the Palermo botanical garden and evaluation of semiochemicals for the control of the key pest Lasioderma serricorne F. (Coleoptera: Anobiidae). J. Cult. Herit. 2020, 43, 37-44. [CrossRef]

31. Guarino, S.; Basile, S.; Arif, M.A.; Manachini, B.; Peri, E. Odorants of Capsicum spp. dried fruits as candidate attractants for Lasioderma serricorne F. (Coleoptera: Anobiidae). Insects 2021, 12, 61. [CrossRef]

32. Edde, P.A. A review of the biology and control of Rhyzopertha dominica (F.) the lesser grain borer. J. Stored Prod. Res. 2012, 48, 1-18. [CrossRef]

33. Gad, H.A.; Al-Anany, M.S.; Abdelgaleil, S.A. Enhancement the efficacy of spinosad for the control Sitophilus oryzae by combined application with diatomaceous earth and Trichoderma harzianum. J. Stored Prod. Res. 2020, 88, 101663. [CrossRef]

34. Edde, P.A. Biology, ecology, and control of Lasioderma serricorne (F.) (Coleoptera: Anobiidae): A review. J. Econ. Entomol. 2019, 112, 1011-1031. [CrossRef] [PubMed]

35. Savoldelli, S.; Jucker, C.; Peri, E.; Arif, M.A.; Guarino, S. Necrobia rufipes (De Geer) infestation in pet food packaging and setup of a monitoring trap. Insects 2020, 11, 623. [CrossRef] [PubMed]

36. Golebiowska, Z. The feeding and fecundity of Sitophilus granarius (L.), Sitophilus orvzae (L.) and Rhyzopertha dominica (F.) in wheat grain. J. Stored Prod. Res. 1969, 5, 143-155. [CrossRef]

37. Padin, S.; Dal Bello, G.; Fabrizio, M. Grain loss caused by Tribolium castaneum, Sitophilus oryzae and Acanthoscelides obtectus in stored durum wheat and beans treated with Beauveria bassiana. J. Stored Prod. Res. 2002, 38, 69-74. [CrossRef]

38. Paolini, J.; Barboni, T.; Desjobert, J.M.; Djabou, N.; Muselli, A.; Costa, J. Chemical composition, intraspecies variation and seasonal variation in essential oils of Calendula arvensis L. Biochem. Syst. Ecol. 2010, 38, 865-874. [CrossRef]

39. Ak, G.; Zengin, G.; Ceylan, R.; Fawzi Mahomoodally, M.; Jugreet, S.; Mollica, A.; Stefanucci, A. Chemical composition and biological activities of essential oils from Calendula officinalis L. flowers and leaves. Flavour Fragr. J. 2021, 36, 554-563. [CrossRef]

40. Raal, A.; Orav, A.; Nesterovitsch, J.; Maidla, K. Analysis of carotenoids, flavonoids and essential oil of Calendula officinalis cultivars growing in Estonia. Nat. Prod. Commun. 2016, 11, 1157-1160. [CrossRef]

41. Okoh, O.O.; Sadimenko, A.A.; Asekun, O.T.; Afolayan, A.J. The effects of drying on the chemical components of essential oils of Calendula officinalis L. Afr. J. Biotechnol. 2008, 7, 1500-1502.

42. Chalchat, J.C.; Garry, R.P.; Michet, A. Chemical composition of essential oil of Calendula officinalis L. Flavour Fragr. J. 1991, 6, 189-192. [CrossRef]

43. Tosun, G.; Yayli, B.; Arslan, T.; Yasar, A.; Alpay Karaoglu, S.; Yayl, N. Comparative essential oil analysis of Calendula arvensis L. extracted by hydrodistillation and microwave distillation and antimicrobial activities. Asian J. Chem. 2012, 24, 1955-1958.

44. Hussein, K.T. Suppressive effects of Calendula micrantha essential oil and gibberelic acid (PGR) on repro ductive potential of the Mediterranean fruit fly Ceratitis capitata Wied. (Diptera: Tephritidae). J. Egypt. Soc. Parasitol. $2005,35,365-377$.

45. Ourabia, I.; Réda, D.; Samira, T.; Nasserdine, S.; Djamila, F.D. Determination of essential oil composition, phenolic content, and antioxidant, antibacterial and antifungal activities of marigold (Calendula officinalis L.) cultivated in Algeria. Carpathian J. Food Sci. Technol. 2019, 11, 93-110. [CrossRef] 
46. Gazim, Z.C.; Rezende, C.M.; Fraga, S.R.; Filho, B.P.D.; Nakamura, C.V.; Cortez, D.A.G. Analysis of the essential oils from Calendula officinalis growing in Brazil using three different extraction procedures. Braz. J. Pharm. Sci. 2008, 44, 391-395. [CrossRef]

47. El-Seedi, H.R.; Azeem, M.; Khalil, N.S.; Sakr, H.H.; Khalifa, S.A.M.; Awang, K.; Saeed, A.; Farag, M.A.; Al Ajmi, M.F.; Pålsson, K.; et al. Essential oils of aromatic Egyptian plants repel nymphs of the tick Ixodes ricinus (Acari: Ixodidae). Exp. Appl. Acarol. 2017, 73, 139-157. [CrossRef] [PubMed]

48. Khalid, K.A.; El-Ghora, A.K. The effect of presowing low temperature on essential oil content and chemical composition of Calendula officinalis. J. Essent. Oil-Bear. Plants 2006, 9, 32-41. [CrossRef]

49. Sahingil, D. GC/MS-Olfactometric Characterization of the volatile compounds, determination antimicrobial and antioxidant activity of essential oil from flowers of Calendula (Calendula officinalis L.). J. Essent. Oil-Bear. Plants 2019, 22, 1-10. [CrossRef]

50. Tirillini, B.; Pagiotti, R.; Angelini, P.; Pintore, G.; Chessa, M.; Menghini, L. Chemical composition and fungicidal activity of the essential oil of Laserpitium garganicum from Italy. Chem. Nat. Compd. 2009, 45, 103-105. [CrossRef]

51. Stanković, N.; Mihajilov-Krstev, T.; Zlatković, B.; Matejić, J.; Stankov Jovanović, V.; Kocić, B.; Čomić, L. Comparative study of composition, antioxidant, and antimicrobial activities of essential oils of selected aromatic plants from Balkan Peninsula. Planta Med. 2016, 82, 650-661. [CrossRef]

52. Popovic, V.B.; Petrovic, S.D.; Milenkovic, M.T.; Drobac, M.M.; Couladis, M.A.; Niketic, M.S. Composition and antimicrobial activity of the essential oils of Laserpitium latifolium L. and L. ochridanum Micevski (Apiaceae). Chem. Biodivers. 2015, 12, 170-177. [CrossRef]

53. Evergetis, E.; Michaelakis, A.; Haroutounian, S.A. Essential Oils of Umbelliferae Family Taxa as Potent Agents for Mosquito Control. In Integrated Pest Management and Pest Control; Larramendy, M.L., Soloneski, L., Eds.; InTech-OpenAccess Publisher: Rijeka, Croatia, 2012; pp. 613-637. Available online: https://www.intechopen.com/books/874 (accessed on 8 December 2021).

54. Petrović, S.; Pavlović, M.; Pavlović, V.; Tzakou, O.; Milenković, M.; Vučićević, D.; Niketić, M. Composition and antimicrobial activity of essential oils from flower and leaf of Laserpitium zernyi Hayek. J. Essent. Oil Res. 2009, 21, 467-470. [CrossRef]

55. Dastan, D.; Salehi, P.; Maroofi, H. Chemical composition, antioxidant, and antimicrobial activities on Laserpitium carduchorum Hedge \& Lamond essential oil and extracts during various growing stages. Chem. Biodivers. 2016, 13, 1397-1403. [CrossRef]

56. Mitic, V.; Stankov-Jovanoviæ, V.; Djordjevic, A.; Ilic, M.; Simonovic, S.; Stojanovic, G. Chemical composition of the essential oil of Laserpitium latifolium from Serbia. Nat. Prod. Commun. 2015, 10, 649-651. [CrossRef]

57. Baser, K.H.C.; Duman, H. Composition of the essential oil of Laserpitium petrophilum Boiss. et Heldr. J. Essent. Oil Res. 1997, 9 , 707-708. [CrossRef]

58. Maggi, F.; Bartolucci, F.; Conti, F. Chemical variability in volatile composition between several Italian accessions of Siler montanum (S. montanum subsp. montanum and S. montanum subsp. siculum). Biochem. System. Ecol. 2017, 70, 14-21. [CrossRef]

59. Jankowska, B.; Wilk, A. Effect of pot marigold (Calendula officinalis L.) and cypress spurge (Euphorbia cyparissias L.) plant water extracts on the occurrence of pest insects on white cabbage. Folia Hortic. 2011, 23, 21-28. [CrossRef]

60. Jankowska, M.; Rogalska, J.; Wyszkowska, J.; Stankiewicz, M. Molecular targets for components of essential oils in the insect nervous system-A review. Molecules 2017, 23, 34. [CrossRef] [PubMed]

61. Gaire, S.; Scharf, M.E.; Gondhalekar, A.D. Toxicity and neurophysiological impacts of plant essential oil components on bed bugs (Cimicidae: Hemiptera). Sci. Rep. 2019, 9, 3961. [CrossRef] [PubMed]

62. Marques, D.M.; Rocha, J.F.; De Almeida, T.S.; Mota, E.F. Essential oils of Caatinga plants with deletary action for Aedes Aegypti: A review. S. Afr. J. 2021, 143, 69-78. [CrossRef]

63. Gross, A.D.; Temeyer, K.B.; Day, T.A.; Pérez de León, A.A.; Kimber, M.J.; Coats, J.R. Interaction of plant essential oil terpenoids with the southern cattle tick tyramine receptor: A potential biopesticide target. Chem. Biol. Interact. 2017, 263, 1-6. [CrossRef]

64. Olmedo, R.; Herrera, J.M.; Lucini, E.I.; Zunino, M.P.; Pizzolitto, R.P.; Dambolena, J.S.; Zygadlo, J.A. Aceite esencial de Tagetes filifolia contra Tribolium castaneum y su relación con la actividad acetilcolinesterasa y peroxidación de lípidos. AgriScientia 2015, 32, 113-121. [CrossRef]

65. Castillo-Morales, R.M.; Carreño Otero, A.L.; Mendez-Sanchez, S.C.; da Silva, M.A.N.; Stashenko, E.E.; Duque, J.E. Mitochondrial affectation, DNA damage and AChE inhibition induced by Salvia officinalis essential oil on Aedes aegypti larvae. Comp. Biochem. Physiol. C Toxicol. Pharmacol. 2019, 221, 29-37. [CrossRef] [PubMed]

66. Guarino, S.; Abbate, L.; Mercati, F.; Fatta Del Bosco, S.; Motisi, A.; Arif, M.A.; Cencetti, G.; Palagano, E.; Michelozzi, M. Citrus varieties with different tolerance grades to Tristeza virus show dissimilar volatile terpene profiles. Agronomy 2021, 11, 1120. [CrossRef]

67. Gu, H.J.; Cheng, S.S.; Huang, C.G.; Chen, W.J.; Chang, S.T. Mosquito larvicidal activities of extractives from black heartwood-type Cryptomeria japonica. Parasitol. Res. 2009, 105, 1455-1458. [CrossRef]

68. Tamdem, G.M.; Ntonga, P.A.; Tsila, H.G.; Tonga, C.; Nkouandou, P.M.; Djeukam, C.A.; Ngaha, R.; Hondt, O.E.N.; Mbongue, R.; Soh, W.T.; et al. Biological activities of the essential oils of Cupressus macrocarpa, Lantana camara and Psidium littorale against Plasmodium falciparum Welch, 1897 and Anopheles gambiae Giles, 1902. J. Entomol. Zool. Stud. 2020, 8, 854-862. [CrossRef]

69. Espinoza, J.; Urzúa, A.; Bandele, L.; Quiroz, A.; Echeverría, J.; González-Teuber, M. Antifeedant effects of essential oil, extracts, and isolated sesquiterpenes from Pilgerodendron uviferum (D. Don) florin heartwood on red clover borer Hylastinus obscurus (Coleoptera: Curculionidae). Molecules 2018, 23, 1282. [CrossRef] [PubMed]

70. Zhang, W.J.; Yang, K.; You, C.X.; Wang, C.F.; Geng, Z.F.; Su, Y.; Wang, Y.; Du, S.S.; Deng, Z.W. Contact toxicity and repellency of the essential oil from Mentha haplocalyx Briq. against Lasioderma serricorne. Chem. Biodivers. 2015, 12, 832-839. [CrossRef] 
71. Teke, M.A.; Mutlu, Ç. Insecticidal and behavioral effects of some plant essential oils against Sitophilus granarius L. and Tribolium castaneum (Herbst). J. Plant Dis. Prot. 2021, 128, 109-119. [CrossRef]

72. Bachrouch, O.; Jemâa, J.B.; Talou, T.; Marzouk, B.; Abderraba, M. Fumigant toxicity of Pistacia lentiscus essential oil against Tribolium castaneum and Lasioderma serricorne. Bull. Insectology 2010, 63, 129-135. 